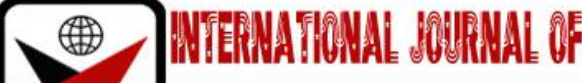

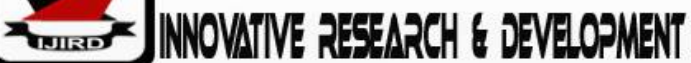

ISSN 2278 - 0211 (Online)

\section{Growth and Yield of Ginger (Zingiber officinale Roscoe) as Influenced by NPK Fertilizer and Moringa Leaves Extracts in a Tropical Ultisol of Nigeria Rainforest}

\author{
Thomas Ogon Ojikpong \\ Lecturer, Department of Agronomy, Cross River University of Technology, Nigeria
}

\begin{abstract}
:
The demand for Ginger is increasing as an important crop in Nigeria. Most farmers in the tropics apply inorganic and organic fertilizers without considering the optimum level that will minimize production cost, maximize yield and profit, reduce fertilizer waste and soil toxicity. A field experiment was conducted at the Teaching and Research Farm of Cross River University of Technology, Obubra during 2017 and 2018 cropping seasonsto investigate the growth and yield response of Ginger to NPK fertilizer and Moringa leaves extracts (MLE). Treatments consisted of four rates of NPK (15:15:15) fertilizer; $\left(0,50,100\right.$ and 150) $\mathrm{kg} \mathrm{ha}^{-1}$ and three rates of MLE; (5,10 and 15) lit. ha-1. The experiment was laid out in a randomized complete block design (RCBD) with three replications. Parameters observed include; plant height, number of leaves per plant, number of primary and secondary rhizomes dry matter yield and rhizome yield. Results obtained showed that application of NPK (15:15:15) at the rate of $150 \mathrm{~kg} \mathrm{ha}^{-1}$ produced tallest plants, highest number of rhizomes and highest rhizome yield while MLE applied at the rate of 15 lit ha-1 produced maximum growth and yield of ginger.
\end{abstract}

Keywords: Ginger, Moringa leaves, extracts NPK fertilizer and rhizomes

\section{Introduction}

Ginger (Zingiber officinale Roscoe) is a tropical perennial plant classified as belonging to the Zingiberaceae family with turmeric, and both have beneficial constituents in their rhizomes - zingiberene. The underground rhizomes are thick, hard and much branched, giving rise to primary, secondary and tertiary rhizomes. The mature roots of ginger are fibrous and the juice from old ginger roots is extremely potent and often used as spices and a quintessential ingredient of Chinese, Korea, Japanese and many South Asian cuisines for flavouring dishes (Jakes, 2007). It is also used largely as recipes such as ginger bread, cookies, crackers, cakes, ginger-ale and ginger beer. The medicinal values of these great ancient spices are widely recognized across the continents to contain a number of unique organic phytochemical ingredients that can take care of some human ailments. Recent studies on health related effects of ginger which have also stimulated farmers concern on the growth of the plant have shown the efficacy of the plant in some life challenging ailments such as entero toxin induced diarrhoea, diabetic nephropathy, nausea, plasma antioxidant, vomiting, high cholesterol, high blood pressure and inflammation(Chen et al., 2007; Ernest and Pittler, 2008; Kim et al., 2008). Ginger oils and oleoresins also have a variety of uses. The essential oil is used in commercial flavorings. Fresh ginger has been used for cold-induced disease, nausea, asthma, cough, colic, heart palpitation, swellings, dyspepsia, loss of appetite, and rheumatism. Ginger contain proteolytic enzymes that promote the digestive process and also enhance the action of the gall bladder and protects the liver against toxins. The cultivation of ginger in recent years especially in the rainforest zone of Nigeria is on the increase (Egbuchua and Enujeke, 2013).Like any other plant, ginger requires the right kind of nutrients to sustain its growth and maximum yield especially in the humid environment where rainfall is high and nutrient reserves are low due to leaching and erosion effects. Plant nutrients usually supplied by the soil in most cases are often inadequate and are sometimes in unavailable forms, hence the need to be augmented with other sources that are cheap and environmentally friendly. The use of organic manures is one technology that has been exploited overtime because of its ability to restore soil fertility, supply major plant nutrients and also stabilizes soil $\mathrm{pH}$.

There is a growing realization that the adoption of ecologically friendly and sustainable farming practices can only reverse the declining trend in the global productivity and environment protection (Aveyard, 1988; Wani et al., 1995). Moringa (Moringa oleifera) is considered as one of the world's most useful trees, as almost every part of the tree has an impressive effect of food, medication and industrial purposes (Khalafalla et al., 2010; Adebayo et al., 2011; Moyo et al., 2011). Moringa leaves are potential source of protein, vitamin A and C, iron, calcium, riboflavin, b-carotene, phenolics (Nambiar et al., 2005). Moringa has attracted enormous attention because of the high levels of macro and micro nutrients in its leaves and a very high capacity of biomass production within a very short period of time (Abdalla and El-Khoshiban, 2012). In recent times, there has been a lot of awareness on the importance of application of organic fertilizer for 
improved crop production as well as environmental sustainability. Applying Moringa leaf extract is a cheap and environment friendly organic technology which increases growth of most vegetable crops like cabbage tomato, maize and common beans. Despite its enormous potentials on the crops, very little information has been reported on the application of Moringa leaf extract on ginger especially in Nigeria. Therefore, the need to investigate the response of ginger to Moringa and to determine the best concentration of Moringa leaf extract and fertilizer that will best be suitable for the production of ginger in Obubra.

\section{Materials and Methods}

Location: The experiment was conducted at the Teaching and Research Farm of the Department of Agronomy, Faculty of Agriculture and Forestry, Cross River University of Technology, Obubra Campus during the 2018 cropping season. The experimental area is located within latitude $06^{\circ} 06^{\prime} \mathrm{N}$ and longitude $08^{\circ} 18^{\prime}$ Eof the equator, and lies significantly in the tropical rainforest zone with over $1,650 \mathrm{~mm}$ of rainfall per annum. The rainfall is bimodal in character with peaks in July and September. The mean temperature is about $37.3^{\circ} \mathrm{C}$; and a relative humidity of about $73.2 \%$ with an altitude of $184 \mathrm{~m}$ above sea level. Land use in the study area is virtually based on rain-fed agriculture and the natural vegetation is typically of rainforest but have been reduced to derived savanna due to repeated clearing and cultivation over the years. The land used for the study had been left fallow for about four years and was not known to have been cultivated to a legume crop for several years previously.

\subsection{Experimental Design and Treatments}

The experiment was laid out in a randomized complete block design (RCBD) and replicated three times. Each experimental plot measured $3 \mathrm{~m} \mathrm{x} 4 \mathrm{~m}\left(12 \mathrm{~m}^{2}\right)$ with an alley of $1 \mathrm{~m}$ between blocks and $0.5 \mathrm{~m}$ between plots. Treatments consisted of four rates of N.P.K. (15:15:15) fertilizer; 0, 50, 100 and $150 \mathrm{~kg} \mathrm{ha}^{-1}$, and three rates of Moringa Leaf Extract (MLE) 5, 10 and 15 lit. ha-1.A distance of $1 \mathrm{~m}$ and $0.5 \mathrm{~m}$ was maintained between the replications and between the plots, respectively. Ten plants from the inner rows of each net plot were randomly selected for the growth and yield parameters.

\subsection{Experimental Materials and Agronomic Practices}

The ginger variety used was UG 1, obtained from the National Roots Crops Research Institute, Umudike, Nigeria. The Moringa leaves extract was prepared using freshly harvested Moringa leaves of not more than 40 days, weighing $2 \mathrm{~kg}$. The leaves were crushed using a porcelain and pestle before diluting with water at a ratio of 1 litre of extract to 10 litres of water. A little quantity of soap was added to the liquid to act as a surfactant before spraying directly on the plant foliage (foliar applied). The rhizomes where planted in situ at a planting distance of $20 \mathrm{~cm}$ x $20 \mathrm{~cm}$ at a depth of $4 \mathrm{~cm}$. Fertilizer was applied using the band placement method at four weeks after planting, while foliar application was used for the MLE. The plots were weeded manually three times at a regular interval of 3 WAP. Ginger was harvested on the $3^{\text {rd }}$ of December in 2017 and $5^{\text {th }}$ of December in 2018 by digging out the rhizomes when the tops had dried up completely. Agronomic data was based on ten randomly selected plants per plot. Plant height, number of tillers and leaves per plant, LA, shoot dry weight, fresh rhizome weight, were the average from each of the ten randomly selected plants, taken at maturity at 26 WAP while the rhizome yield was based on the net plot yield.

\section{Data Collection}

\subsection{Soil Sampling and Processing}

Prior to planting, a composite soil sample was taken randomly for each year using a soil auger to a depth of $30 \mathrm{~cm}$. The sample was air-dried and sieved to pass through a $2 \mathrm{~mm}$ sieve for routine soil physicochemical analysis in the laboratory.

\subsection{Plant Sampling}

A net plot of $2 \mathrm{~m} \times 2 \mathrm{~m}\left(4 \mathrm{~m}^{2}\right)$ with three inner rows in each plot was used with ten tagged plants for measurements. The rhizome yield for each net plot was extrapolated to yield in tonnes per hectre. Destructive sampling was used in determining the above ground shoot dry matter weight of ginger.

\subsection{Soil Analysis}

The pre-planting soil analysis was carried out in the Faculty of Agriculture Standard Laboratory, Federal University of Agriculture, Makurdi, Benue State, Nigeria. The Particle size distribution was determined by the Bouyoucos (Hydrometer) method as described by Udo et al., (2009). Soil pH was determined from the filtered suspension of 1:2.5 soil to water ratio using a glass electrode attached to a digital pH meter (Udo et al., 2009). Soil organic matter was determined by the Walkley and Black wet digestion method as outlined by Page et al., (1982). Total nitrogen was determined by the Macro Kjeldhal method as described by (Udo et al., 2009). Available phosphorus was determined by the Molybdate blue colorimetry method using Spectrophotometer. Exchangeable cations were determined by the Ammonium Acetate (NH4 OAC) extraction method as described by Udo et al., 2009.

\subsection{Statistical Analysis}

Statistical analysis was performed on the data according to the procedures for RCBD using GENSTAT (2005) edition. Comparison of treatment means for significance was done using least significant difference (LSD) procedure at 5 percent probability level as described by Gomez and Gomez (1984). 


\section{Results and Discussion}

Result of soil properties of the experimental site is presented in Table 1. The results show that the soil of the site was sandy loam with pHof 5.72 indicating that the soil is moderately acidic. The soil organic matter was low as well as soil nitrogen which was $0.09 \%$. The available phosphorus was low $(11.10 \mathrm{mg} / \mathrm{kg})$. The exchangeable cations were low with the exception of magnesium which was $2.64 \mathrm{cmol} / \mathrm{kg}$. The CEC was moderate $(11.56 \mathrm{cmol} / \mathrm{kg})$ with a base saturation of $79.2 \%$. The soil nutrient levels were rated low according to the classification of fertility grades by Dauda et al. (2003). Excessive leaching due to high rainfall, coupled with the sandy nature and low organic matter content, soils in southeastern Nigeria have low cation exchange capacities and therefore lose fertility rapidly (Chude et al., 2004).

Result of plant height and number of leaves per plant and leaf area (LA) is presented in Table 2. The result showed that application of Moringa leaves extract and N.P.K. fertilizer significantly $(\mathrm{P}<0.05)$ influenced the plant height, number of leaves produced per plant and the LA in both 2017 and 2018. The application of N.P.K. (15:15:15) at the rate of $150 \mathrm{~kg} / \mathrm{ha}$, produced tallest plants $(83.1 \mathrm{~cm})$.This was followed by application of N.P.K. (15:15:15) at $100 \mathrm{~kg} / \mathrm{ha}(66.9 \mathrm{~cm})$. The application of Moringa leaves extract(MLE) at the rate of 15lit/ha produced significantly the same plant height with the 50 $\mathrm{kg} /$ ha rate of NPK application. The least plant height was obtained in the control with $0 \mathrm{~kg} / \mathrm{ha}$. This result is in conformity with the findings by Nishina et al., (1992) who reported that Ginger requires a high nutrient supply for optimum growth and yield. The number of leaves produced per Ginger plant was at maximum (16.5) with the application of NPK at the rate of $150 \mathrm{~kg} /$ ha. However, more leaves were produced (14.6) when Moringa leaves extracts was applied at the rate of 15 lit/ha than at 5 lit./ha rate. The response of ginger to higher rates of fertilizer has been reported by Attoe and Osodeke (2009). Similarly, the highest LA was produced with the application of NPK fertilizer at the rate of $100 \mathrm{~kg} \mathrm{ha}^{-1}$.

The results of number of tillers and rhizomes per plant and rhizome yield is presented in Table 3. Number of ginger tillers, rhizomes and rhizome yield was significantly $(\mathrm{P}<0.05)$ influenced by fertilizer application and Moringa leaves extract, except in 2017. The application of N.P.K. fertilizer at the rate of $150 \mathrm{~kg} /$ ha gave significantly higher number of tillers (4.8 and 4.2 in 2017 and 2018, respectively). This was followed by $100 \mathrm{~kg} / \mathrm{ha}$ rate of N.P.K. (15:15:15) application which gave 3.3 and 3.8 in 2017 and 2018, respectively. While Moringa leaves extract at the rate of 10 lit/ha produced 2.2 and 2.6 tillers in 2017 and 2018, respectively. The least number of tillers was obtained in the control where no fertilizer was applied. The significant increase in tiller and rhizome number is indicative that ginger responds positively to fertilizer as reported by Rao and Swamy (1984). Foidl et al., (2001) reported that juice or extracts from fresh Moringa leaves produce an effective plant growth hormone which increases yields by $25-30 \%$ for nearly all crops. The significant increase in the growth and yield of ginger due to the application of Moringa leaves extract also agrees with the findings of Ojikpong, (2018), who reported that foliar application of Moringa leaves extract promotes rapid vegetation, hence the abundant growth in leaves and rhizomes that significantly increased the yield of ginger. The improvement in growth and yield resulted from the influence of zeatin, a plant growth hormone which is present in the Moringa oleifera plant.

Ginger has a high nutrient demand from the soil, hence the need for fertilizer application (Nishina et al., 1992). Among all the nutrients elements, nitrogen was the major limiting nutrient militating against massive production of ginger (Njoku, 1989)and studies also confirmed that the optimum NPK treatment combination of 200:80:100kg/ha gave the best rhizome yield (Attoe and Osodeke, 2009). Mohanty et al.; (1993) observed that the yield of ginger rhizomes increased with increasing fertilizer application rates. The maximum yield of $10.16 \mathrm{t} \mathrm{ha}^{-1}$ was recorded in the highest fertilizer application of $\mathrm{N}$ : P: K at the rate of $(125: 70: 150) \mathrm{kg}$ per ha.

\section{Conclusion}

The use of fertilizer is essential for the production of spices like ginger especially where the soil nutrient might not be adequate. There is a significant increase in the growth and yield of ginger due to the application of Moringa leaves extract and NPK fertilizer. The improvement in growth and yield as a result of the application of Moringa leaves extract, resulted from the influence of zeatin, a plant growth hormone which is present in the Moringa oleifera plant. From the results of this experiment, it is possible to have further significant increases in the growth and yield of ginger with further increases in the rates of Moringa leaf extracts.

\begin{tabular}{|c|c|c|}
\hline Soil property & 2017 & 2018 \\
\hline Sand (\%) & 85.62 & 78.5 \\
\hline Silt (\%) & 5.98 & 13.5 \\
\hline Clay (\%) & 10.50 & 8.0 \\
\hline Textural class & Sandy-loam & Sandy loam \\
\hline $\mathrm{pH}\left(\mathrm{H}_{2} \mathrm{O}\right)$ & 5.72 & 5.48 \\
\hline Organic matter (\%) & 3.49 & 2.66 \\
\hline Total nitrogen (\%) & 0.09 & 0.15 \\
\hline Available P (Mg/kg) & 11.10 & 15.46 \\
\hline $\mathrm{Ca}(\mathrm{Cmol} / \mathrm{kg})$ & 7.20 & 8.40 \\
\hline $\mathrm{K} \mathrm{Cmol} / \mathrm{kg}$ & 0.21 & 0.48 \\
\hline $\mathrm{Mg} \mathrm{Cmol} / \mathrm{kg}$ & 2.64 & 1.54 \\
\hline $\mathrm{Na} \mathrm{Cmol} / \mathrm{kg}$ & 0.08 & 0.11 \\
\hline ECEC Cmol/kg & 2.86 & 2.83 \\
\hline Base saturation (\%) & 94.85 & 90.3 \\
\hline
\end{tabular}

Table 1: Pre-planting Soil Properties of the Experimental Site for 2017 and 201 


\begin{tabular}{|c|c|c|c|c|c|c|}
\hline Treatment & \multicolumn{2}{|c|}{ Plant Height (Cm) } & \multicolumn{2}{c|}{$\begin{array}{c}\text { Number of Leaves } \\
\text { Per Plant }\end{array}$} & \multicolumn{2}{c|}{ Leaf Area (LA) } \\
\hline & $\mathbf{2 0 1 7}$ & $\mathbf{2 0 1 8}$ & $\mathbf{2 0 1 7}$ & $\mathbf{2 0 1 8}$ & $\mathbf{2 0 1 7}$ & $\mathbf{2 0 1 8}$ \\
\hline NPK 0 kg /ha & 40.1 & 48.8 & 12.2 & 17.0 & 198.2 & 205.2 \\
\hline NPK 50 kg/ha & 57.4 & 46.0 & 14.5 & 22.0 & 210.5 & 220.5 \\
\hline NPK 100 kg/ha & 66.9 & 58.0 & 15.3 & 23.7 & 218.7 & 225.0 \\
\hline NPK 150 kg/ha & 83.1 & 66.7 & 16.5 & 24.7 & 231.8 & 230.4 \\
\hline MLE 5 lit/ha & 42.5 & 52.0 & 13.4 & 19.3 & 222.5 & 235.3 \\
\hline MLE 10 lit/ha & 49.1 & 57.3 & 13.5 & 18.0 & 224.0 & 238.6 \\
\hline MLE 15 lit/ha & 55.0 & 56.2 & 14.6 & 22.2 & 228.9 & 246.5 \\
\hline LSD (P<0.05) & 6.3 & 3.8 & 0.68 & 0,86 & 12.5 & 18.6 \\
\hline
\end{tabular}

Table 2: Plant Height, Number of Leaves and Leaf Area of Ginger as

Influenced By N.P.K. (15:15:15) Fertilizer and Moringa Leaves Extract

\begin{tabular}{|c|c|c|c|c|c|c|}
\hline Treatment & \multicolumn{2}{|c|}{$\begin{array}{c}\text { Number of } \\
\text { tillers/plant }\end{array}$} & \multicolumn{2}{c|}{$\begin{array}{c}\text { Number of } \\
\text { Rhizomes / plant }\end{array}$} & \multicolumn{2}{c|}{ Rhizome length (cm) } \\
& 2017 & 2018 & 2017 & 2018 & 2017 & 2018 \\
\hline & 1.7 & 1.3 & 2.7 & 2.5 & 6.5 & 5.3 \\
\hline NPK 0 kg /ha & 2.1 & 2.6 & 3.8 & 3.9 & 7.5 & 6.7 \\
\hline NPK 50 kg/ha & 3.3 & 3.8 & 3.9 & 4.2 & 10.1 & 8.5 \\
\hline NPK 100 kg/ha & 4.8 & 4.2 & 4.0 & 4.8 & 13.0 & 12.4 \\
\hline NPK 150 kg/ha & 1.8 & 2.2 & 3.5 & 3.4 & 5.3 & 5.4 \\
\hline MLE 5 lit/ha & 2.2 & 2.6 & 2.6 & 2.5 & 6.2 & 5.6 \\
\hline MLE 15 lit/ha & 2.5 & 2.6 & 3.7 & 3.5 & 7.2 & 6.5 \\
\hline LSD (P<0.05) & 1.32 & 2.10 & NS & 1.62 & 3.53 & 4.32 \\
\hline
\end{tabular}

Table 3: Number of Primary and Secondary Rhizomes, and Rhizome Weight of

Ginger as Influenced by N.P.K. (15:15:15) Fertilizer and Moringa Leaves Extract

\begin{tabular}{|c|c|c|c|c|c|c|}
\hline Treatment & \multicolumn{2}{|c|}{ Dry matter yield } & \multicolumn{2}{c|}{ Rhizome weight (g) } & \multicolumn{2}{c|}{ Rhizome yield (t/ha) } \\
\hline & 2017 & 2018 & 2017 & 2018 & 2017 & 2018 \\
\hline NPK 0 kg /ha & 6.7 & 6.5 & 34.9 & 30.3 & 5.8 & 4.8 \\
\hline NPK 50 kg/ha & 9.4 & 9.9 & 53.2 & 45.2 & 7.2 & 6.9 \\
\hline NPK 100 kg/ha & 10.6 & 11.5 & 42.0 & 52.0 & 8.8 & 7.8 \\
\hline NPK 150 kg/ha & 14.8 & 15.3 & 65.3 & 58.4 & 11.3 & 10.2 \\
\hline MLE 5 lit/ha & 7.4 & 8.5 & 45.2 & 35.4 & 6.6 & 6.3 \\
\hline MLE 10 lit/ha & 7.8 & 8.2 & 45.7 & 43.2 & 7.2 & 6.7 \\
\hline MLE 15 lit/ha & 8.0 & 9.0 & 47.6 & 48.5 & 8.6 & 7.4 \\
\hline LSD (P< 0.05) & 4.2 & 3.5 & 12.4 & 10.8 & 5.8 & 4.8 \\
\hline
\end{tabular}

Table 4: Dry Matter Yield, Rhizome Weight and Rhizome Yield of Ginger as Influenced by N.P.K. (15:15:15) Fertilizer and Moringa Leaves Extract

\section{References}

i. Abdalla, M.M, and El-Khoshiban, N. (2012). The palliative effect of bio-organic fertilizer on lead pollution in Lycopersicum esculentumplants.J. Basic App. Sci. 8: 1-

ii. Adebayo, A.G, Akintoye, HA, Olufolaji, 0.0, Aina, MT, Olatunji, MT and Shokalu A0. (2011). Assessment of organic amendments on vegetative development and nutrient uptake of Moringa oleifera Lam. in the nursery. Asian J. Plant Sci.10 (1): 74-

iii. Asumugha, G.N, Ayaegbunam, H.N;,Ezulike, T.O.,Nwosu, K.L. (2006). Guide to ginger production and marketing in Nigeria. National Root Crops Research Institute, Umudike Nigeria. Ext.Guide 7:1-7.

iv. Attoe, E.E. and Osodeke, V.E., 2009. Effects of NPK on growth and yield of Ginger Zingiber Officinale Roscoe in Soils of contrasting parent materials of Cross River State. Electronic Journal of Environmental Agriculture and Food Chemistry, 8 11:1261-1268.

v. Aveyard, J. (1988). Land degradation changing attitude, Journal of soil conservation, New South Wales, 44:46-52.

vi. Bremmer JM,Mulvaney CS (1982).Total nitrogen, In: Page A. L; Miller,. R. H. and Keeney, D. R(ed): Methods of soil analysis Part 2. Agron. 9. Madison, WI, USA. pp. 149-157.

vii. Chude, V.O., Malgwi, I.V., Amapu, I.V. and Ano, A.A. (2004). Manuel on soil fertility Assessment. Federal Fertilizer Department/ National Special Programme for Food Security, Abuja, Nigeria. 48pp.

viii. Egbuchua, C. N. and Enujeke, E. C. (2013). Growth and yield responses of ginger (Zingiber officinale) to three sources of organic manures in a typical rainforest zone, Nigeria. J. Hortic. For. Vol. 5(7): 109-114.

ix. Foidl, N, Makkar, H.P.S and Becker, K (2001). The potential of Moringa oleifera for agricultural and industrial uses, PP 45-76 in: The miracle Tree. The multiple Attributes of Moringa (Ed) Lowell J. Fuglie, CTA, Wagenningen, the Netherlands. 
x. Gee GW. Bauder JW (1986). Particle size analysis. In: Klute, A. (ed.). Methods of soil analysis Part 2. Chemical and microbiological properties. 2nd edition. Agron. Monograph 9. Madison, W.I. USA.

xi. Genstat Release 4.24 Edition (PC/Windows XP) Copy right, (2005). Laves Agricultural Trust (Ruthamstat Experimental Station) Discovery ed. 2

xii. Gomez, K.A. and Gomez, A.A. (1984). Statistical Procedures for Agricultural Research. 2 ${ }^{\text {nd }}$ ed. John Wiley and sons; New York, USA 680pp.

xiii. IITA-International Institute of Tropical Agriculture (1982).Automated and semi-automated of and plant analysis. Manual series No. 7. IITA,Ibadan, Nigeria.

xiv. Kekong M.A, Ali A and Ojikpong T.O. (2014). Soil nitrogen status and garden egg (Solanum aethiopicum) yield as influenced by Moringa oleifera leaves and poultry manure in two Nigerian Agro-ecologies. J. of Dynamics in Agricultural Research Vol.1(2), pp.5-13.

xv. Khalafalla M.M, Abdellatef E, Dafalla HM, Nassrallah AA, Aboul-Enein KM, Lightfoot D.A, Eldeeb F.E, El-Shemy HA. (2010). Active principle from Moringa oleiferaLam. leaves effective against two leukemais and a hepatocarcinoma. Afr. J. Biotechnol., 9(49): 8467-8471. Mohanty, D. C., Sarma, Y. N., Panda B.S., Edison, S. (1993). Studies on fertilizer management and seed rates in ginger variety - Suruchi. Indian Cocoa, Arecanut and Spices Journal. 16 (3-4): 101104.

xvi. Moyo B, Masika PJ, Hugo A, Muchenje V. (2011). Nutritional characterization of Moringa (Moringa oleiferaLam.) leaves. Afr. J.Biotechnology, 10(60): 12925-12933.

xvii. Nishina, W.A., Gupta, A. and Arun, S. 1992. Ginger production in Asian - sub continent. New York, John Willey and Sons.

xviii. Njoku, B.O. 1989. Influence of Nitrogen, Phosphorus and Potassium on the performance of ginger at three locations. Annual Report. Umudike, Root Crop Research Institute.

xix. Nambiar V.S, Rachana Mehta, Daniel M. (2005). Polyphenol content of three Indian green leafy vegetables. J. Food Sci. Technol., 42(6): 312-315.

xx. Ojeniyi, S.O. 2010. Tropical Soil Management and Agriculture in Nigeria. Bash Moses Publishers, Ibadan, Nigeria.

xxi. Ojikpong, T.0. 2018. The effects of Moringa (Moringa oleifera Lam) leaves and NPK (15:15:15) fertilizer on the growth parameters and yield of soybean (Glycine max L. Merrill) in Obubra, south Eastern region of Nigeria. Int. J. of Agriculture, Environment and Bioresearch. Vol. 3 (4): 84-92.

xxii. Rhoades JD (1982). Cation exchange capacity. In: Page A. L., Miller, R. H. and Keeney, D.R. (ed), Methods of soil analysis. Part 2. Agron. 9 Madison. W. I. pp. 149-157.

xxiii. Undie, U.L, Kekong, M.A. and Ojikpong, T.O. 2013. Moringa (Moringa oleifera Lam) leaves effect on soil pH and garden egg (Solanum aethiopicum L.) yield in two Nigeria agro-ecologies. European J. of Agric. And For. Res.Vol. 1(1): 17-25.

xxiv. Wani S.P, Rupeta OP, Lee K.K. 1995. Sustainable agriculture in the semi-arid tropics through biological nitrogen fixation in plant soil, 174:29:49 